\title{
POPULATION GROWTH AND DEVELOPMENT OF TWO SPECIES OF CLADOCERA, Moina micrura AND Diaphanosoma birgei, IN LABORATORY
}

\author{
SIPAÚBA-TAVARES, L. H. and BACHION, M. A. \\ Centro de Aqüicultura, Unesp, Via de Acesso Prof. Paulo Donato Castellane s/n, Jaboticabal, \\ CEP 14870-000, SP, Brazil \\ Correspondence to: Lúcia Helena Sipaúba Tavares, Centro de Aqüicultura, Unesp, Via de Acesso Prof. Paulo \\ Donato Castellane s/n, Jaboticabal, CEP 14870-000, SP, Brazil, e-mail: sipauba@ caunesp.unesp.br \\ Received May 14, 2001 - Accepted October 23, 2001 - Distributed November 30, 2002
}

(With 3 figures)

\begin{abstract}
The objective of the present work was to investigate the influence of four diets on population growth, development, total length, dry weight, and nutritional value of two zooplanktonic species, Moina micrura and Diaphanosoma birgei. The four dietary treatments were: algae alone (A); algae + vitamins (AV); algae + ration (AR); and algae + ration + vitamins (ARV). Growth rate peak for both species occurred faster with AV treatment. In general, AV treatment for M. micrura showed better results for intrinsic rate, fecundity, and embryonic and post-embryonic development. On the other hand, longevity and total spawning number were better with AR treatment $(\mathrm{p}<0.05)$. Vitamin and ration treatments produced the best results in $D$. birgei species $(\mathrm{p}<0.05)$. The highest percentage of protein and lipids for both cladocerans was verified for ration treatments. Carbohydrate was higher for the treatment containing algae alone $(\mathrm{p}<0.05)$. Generally, diets containing ration and vitamin showed better results in cladocerans development, with water quality adequate for culture systems. Ration and vitamin diets may also be used in high-density cultures in the laboratory.
\end{abstract}

Key words: zooplankton, population growth, biochemical composition, algae.

\section{RESUMO}

\section{Influência da dieta alimentar (alga + suplemento) no crescimento e desenvolvimento populacional de duas espécies de Cladocera, Moina micrura e Diaphanosoma birgei, em laboratório}

O objetivo do presente trabalho foi testar a influência de quatro dietas alimentares sobre o crescimento populacional, desenvolvimento, comprimento total, peso seco e valor nutricional de duas espécies zooplanctônicas, Moina micrura and Diaphanosoma birgei, com os seguintes tratamentos alimentares: somente alga (A), alga + vitaminas (AV), alga + ração (AR) e alga + ração + vitaminas (ARV). O pico de crescimento para as duas espécies estudadas ocorreu mais rápido no tratamento AV. Em geral, o tratamento AV para M. micrura mostrou melhores resultados para taxa intrínseca, fecundidade, desenvolvimento embrionário e pós-embrionário. Já a longevidade e número total de desovas apresentaram melhores resultados no tratamento AR $(\mathrm{p}<0,05)$. Para $D$. birgei, os melhores resultados foram obtidos nos tratamentos contendo ração e vitamina $(\mathrm{p}<0,05)$. A maior porcentagem de proteínas e lipídeos para os dois cladóceros ocorreu nos tratamentos contendo ração, já o carboidrato foi maior no tratamento contendo somente alga $(\mathrm{p}<0,05)$. Em geral, as dietas contendo ração e vitamina apresentaram os melhores resultados para o desenvolvimento dos cladóceros, com qualidade de água adequada para cultivo, podendo ser utilizadas em culturas com altas concentrações em laboratório.

Palavras-chave: zooplâncton, crescimento populacional, composição bioquímica, alga. 


\section{INTRODUCTION}

In Brazil, few studies have emphasized plankton development and its nutritive value (Rocha \& Matsumura-Tundisi, 1990; Hardy \& Duncan, 1994; Sipaúba-Tavares et al., 1994; Hardy \& Castro, 2000; Macedo \& Pinto-Coelho, 2000).

Cladocerans culture offers the possibility of obtaining a large number of individuals quickly under appropriate conditions of temperature, food, and water quality, due to parthenogenetic reproduction of these organisms.

Zooplankton reproduction and growth rate increases result in higher availability and, sometimes, better food quality for subsequent trophic levels.

Currently, a large variety of live organisms is used in larviculture, mainly due to their superior nutritional value as compared to that of formulated diets. Natural diets include different species of phytoplankton, zooplankton, and invertebrate larvae. However, some species have been selected as food sources in larviculture based on the following criteria (Watanabe \& Kiron, 1994):

- Physical qualities such as purity, availability, and acceptance;

- Nutritional indicators, such as digestibility and organism nutrients/energy;

- Easily obtainable;

- Easy reproduction;

- Economically feasible.

Moina micrura and Diaphanosoma birgei species were chosen because of their virtual yearround presence in fishponds. In addition, they are resistant to the handling involved in the culture system and are selected as food by fish larvae.

According to Fim (1992) and SipaúbaTavares \& Braga (1999), since tambaqui and pacu larvae feed on $M$. micrura and $D$. birgei during their first days, these are promising species for possible use as food in larviculture.

For herbivorous zooplanktonic organisms, algae are the main food source; however, food quantity and quality are important factors controlling zooplankton development, growth, and reproduction.

Vitamins have also been added to algae culture used as food by zooplankton and result in significant increase in organism production.

The laboratory study of planktonic organisms will provide input useful for large-scale production.
Increases knowledge of their biology and the influence of factors such as temperature, food type on population growth, and zooplankton nutritional value will allow adaptation of culture conditions to ensure plankton culture success.

The objective of this study was to verify the influence of diets (algae + supplement) on the development of two Cladocera species, Moina micrura and Diaphanosoma birgei. In the laboratory life cycle of both species were studied, focusing on growth, development period, reproduction, and biochemical composition. The influence of water quality on culture was also investigated.

\section{MATERIALS AND METHODS}

\section{Zooplankton collection}

Moina micrura and Diaphanosoma birgei were collected in fishponds $\left(21^{\circ} 15^{\prime} \mathrm{S} ; 48^{\circ} 18^{\prime} \mathrm{W}\right)$ using $58 \mu \mathrm{m}$ mesh-size plankton net. Acclimation period in the laboratory lasted 2 months. The specimens were placed in $2 \mathrm{~L}$ glass bottles filled with filtered fishpond water (filter GFC, $0.47 \mu \mathrm{m}$ pore) at $25 \pm 1{ }^{\circ} \mathrm{C}$ and only fed Ankistrodesmus gracillis algae. Before beginning the experiment, they were not fed for 24 hours to empty the digestive tract.

\section{Food supply}

The algae used, Ankistrodesmus gracillis, originated in São Carlos University collection number $005 \mathrm{CH}$ and was isolated from Broa Reservoir (SP, Brazil).

The algae species were batch-cultured in the laboratory at $24^{\circ} \mathrm{C}, \mathrm{D}$ light regime 5,200 lux, and fertilized with NPK (Sipaúba-Tavares, 1995). Stock culture was maintained in $2 \mathrm{~L}$ flasks; during this time the flasks were refilled with filtered fresh water and fertilized as required. Mean cell size was $23.8 \times 3.3 \mu \mathrm{m}$.

To evaluate $M$. micrura and $D$. birgei growth and development rates, the cultures were initiated with 15 females, and 4 diets were tested daily over a 15-day period. The 4 treatments were as follows: 1. algae alone (A), at 3 to $4 \times 10^{6}$ cells/mL density; 2. algae + vitamin (AV), B vitamin complex varying from 2 to $4 \mathrm{mg}$, according to population growth; 3. algae + ration (AR), commonly used to feed fish larvae, varying from 0.05 to $0.1 \mathrm{~g}$; and 4. a diet containing all three ingredients (ARV). 


\section{Growth rate}

Cladocerans were maintained in laboratory stocking culture and 15 ovigerous females (approximately 4 eggs/female) were selected and isolated. The cultures were kept under constant light (300 lux), in 1,800 $\mathrm{mL}$ volume, at $25 \pm 1^{\circ} \mathrm{C}$ temperature for a 15 day-period.

Population growth was monitored daily by counting the number of organisms, using a Wild-Leitz M-5 Wild Heerbrugg MDG-17 stereomicroscope.

About 150 organisms at each developmental stage (neonate, young, and adult) were measured to monitor total length and dry weight.

Duration of embryonic (hours) and postembryonic (days) developmental stages, total number of offspring/female, mean fecundity (number of neonate/offspring/female), and longevity (days) were monitored for each organism until natural death occurred. The experiments were conducted with six replicates.

Cladocerans' potential growth was determined using intrinsic rate of natural increase, under defined laboratory conditions (Bottrell et al., 1976; Vijverberg, 1989).

\section{Biochemical composition}

Protein was analyzed according to Lowry et al. (1951) using bovine albumin, and carbohydrates according to Dubois et al. The method (1956) using glucose solution and lipids by sulpho-phosphovanillin method was also used, through chemical digestion proposed by Meyer \& Walter (1988).
Dry weight was determined with a Mettler precision balance (accuracy $\pm 0.1 \mu \mathrm{m}$ ) according to the Berberovic \& Pinto-Coelho method (1989).

\section{Hydrological data}

To evaluate the effect of the diets on the water quality, several limnological parameters were analyzed as shown in Table 1.

\section{Data analysis}

Comparison among mean values of different biological treatments was made by the Tukey test (Pimentel-Gomes, 1976). Different dietary treatments were analyzed by entirely randomized design (ERD) due to homogeneity of experimental conditions.

\section{RESULTS}

\section{Growth}

Moina micrura organisms fed algae + vitamin (AV) reached growth peak faster, on the eighth day, and the average value was $3,915 \mathrm{ind} / \mathrm{L}$. This result was followed by that of organisms fed algae alone (A), algae + ration (AR), and algae + ration + vitamin (ARV), which reached growth peak between the $11^{\text {th }}$ and $14^{\text {th }}$ days, with average values of 3,880, 3,830, and 6,383 ind/L, respectively.

Diaphanosoma birgei growth rate was similar to that of $M$. micrura. The 4,593 ind/L average value was reached on the $10^{\text {th }}$ day with $\mathrm{AV}$ treatment, followed by 3,927 ind/L for A, 4,517 ind/L for AR, and 5,608 ind/L for ARV reached between the $12^{\text {th }}$ and $14^{\text {th }}$ days.

TABLE 1

Limnological variables analysed.

\begin{tabular}{|l|l|}
\hline \multicolumn{1}{|c|}{ Limnological variables } & \multicolumn{1}{c|}{ Methods } \\
\hline $\mathrm{pH}$ & Corning PS $15 \mathrm{pH}$ meter \\
\hline Electrical conductivity & Corning PS 17 conductivity meter \\
\hline Dissolved oxygen & Winkler method Golterman et al. (1978) \\
\hline Total alkalinity and $\mathrm{CO}_{2}$ & Mackereth et al. (1978) \\
\hline Ammonia & Koroleff (1976) \\
\hline Nitrite and nitrate & Golterman et al. $(1978)$ \\
\hline Total phosphorus and orthophosphate & Golterman et al. (1978) \\
\hline Chlorophyll $a$ & Golterman et al. (1978) \\
\hline
\end{tabular}


Average maximum number of organisms per liter was significantly different $(p<0.05)$ for ARV treatment in both species. The other treatments did not show significant differences $(\mathrm{p}>0.05)$.

The highest intrinsic rate of natural increase (r) was obtained through AV treatment, with $\mathbf{r}$ values of 0.69 and 0.57 for $M$. micrura and $D$. birgei, respectively. This treatment also resulted in faster reaching of growth peak (Table 2).

Treatment AV for M. micrura was better with respect to embryonic and post-embryonic development, as well as fecundity. Treatment AR and ARV $(\mathrm{p}<0.05)$ resulted in longer periods of embryonic and post-embryonic development, totaling 34.46 hours and 2.13 days, respectively (Table 2).

Number of offspring for treatments containing ration (AR and $A R V$ ) was higher compared to that for algae (A) and algae + vitamin (AV) treatments, averaging 3.97 and 3.05 offspring/females, respectively (Table 2).

For species $M$. micrura, average longevity was not significantly different among treatments $(\mathrm{p}>0.05)$. However, it was slightly higher for diet AR, by a 6-day average (Table 2).

For species $D$. birgei, fecundity was higher for ARV and AV treatments $(\mathrm{p}<0.05)$, with averages of 8.66 and 8.15 neonate/offspring/female, respectively. Total number of offspring/female was higher for treatments containing vitamins $(\mathrm{p}<$ 0.05), AV and ARV, with average values of 10.08 and 7.65 offspring/female, respectively. Embryonic development under AV treatment $(\mathrm{p}<0.05)$ lasted 44.91 hours, and post-embryonic development was faster for A treatment $(\mathrm{p}<0.05)$, lasting 2.26 days. Treatments containing vitamins (AV and ARV) showed the best longevity results, a 16-day average (Table 2).

For $M$. micrura cladocera, average length varied from 740.87 to $776.77 \mu \mathrm{m}$ for adult females; 606.33 to $638.06 \mu \mathrm{m}$ for juveniles; and 486.39 to $502.78 \mu \mathrm{m}$ for neonates. As for D. birgei, which is larger than M. micrura, average length varied from 929.56 to $961.57,608.53$ to 653.65 , and 438.16 to $475.56 \mu \mathrm{m}$ for adult females, juveniles, and neonates, respectively (Fig. 1).

M. micrura adult females were larger when fed A, AV, and AR ( $\mathrm{p}<0.05)$ diets, while juveniles were larger when fed the ARV diet $(p<0.05)$. Neonate average length was not significantly different for any of the diets $(\mathrm{p}>0.05)$. D. birgei average length at different developmental stages differed only slightly for all diets (Fig. 1).

Average dry weight varied between the two species for different diets. It ranged from 3.29 to $3.74 \mu \mathrm{g}$ and 5.68 to $6.28 \mu \mathrm{g}$ for adult females; 2.52 to $2.90 \mu \mathrm{g}$ and 3.09 to $4.44 \mu \mathrm{g}$ for juveniles; and 0.18 to $0.22 \mu \mathrm{g}$ and 0.26 to $0.35 \mu \mathrm{g}$ for neonates of M. micrura and D. birgei, respectively (Fig. 2).

Average dry weight of $M$. micrura adult females was higher for the AV and AR diets, and that of juveniles for the AV diet $(p<0.05)$. On the other hand, neonate dry weight was not significantly different for any diet $(\mathrm{p}>0.05)$. $D$. birgei neonates and adult females presented higher dry weight under AV treatment ( $\mathrm{p}<0.05$ ). However, juveniles showed better results with AV and AR treatments $(\mathrm{p}<0.05)$ (Fig. 2).

\section{Biochemical composition}

For cladocerans M. micrura and D. birgei, the highest protein percentages were found for ARV treatment $(\mathrm{p}<0.05), 80.23 \%$ and $76.40 \%$, respectively. For these two species, protein levels for $\mathrm{AV}$ and AR treatments were similar, and the lower percentages were found for treatment A, 56.40\% and $58.47 \%$, respectively (Fig. 3).

As for carbohydrate percentages, an opposite trend was found, i.e., the highest values were found for treatment A $(\mathrm{p}<0.05)$, reaching values of $34.33 \%$ and $21.29 \%$ for M. micrura and D. birgei, respectively. The AR and ARV treatments yielded the lowest carbohydrate percentages, with average values of $13.53 \%$ and $11.89 \%$, respectively (Fig. 3).

There was no significant difference with respect to lipids for $D$. birgei among the diets $(\mathrm{p}>0.05)$. As for M. micrura, ARV yielded the highest value $(\mathrm{p}<0.05)$ compared to others, with a $21.5 \%$ average (Fig. 3).

\section{Limnological characteristics}

Some limnological variables were influenced by the water supply (from a well). However, the values found for the treatments were appropriate for organism culture, mainly due to nitrite and ammonia low concentrations. Nitrogen compounds were directly influenced by the well water, which was contaminated by chemical fertilizer due to agricultural activities in the area (Table 3 ). 


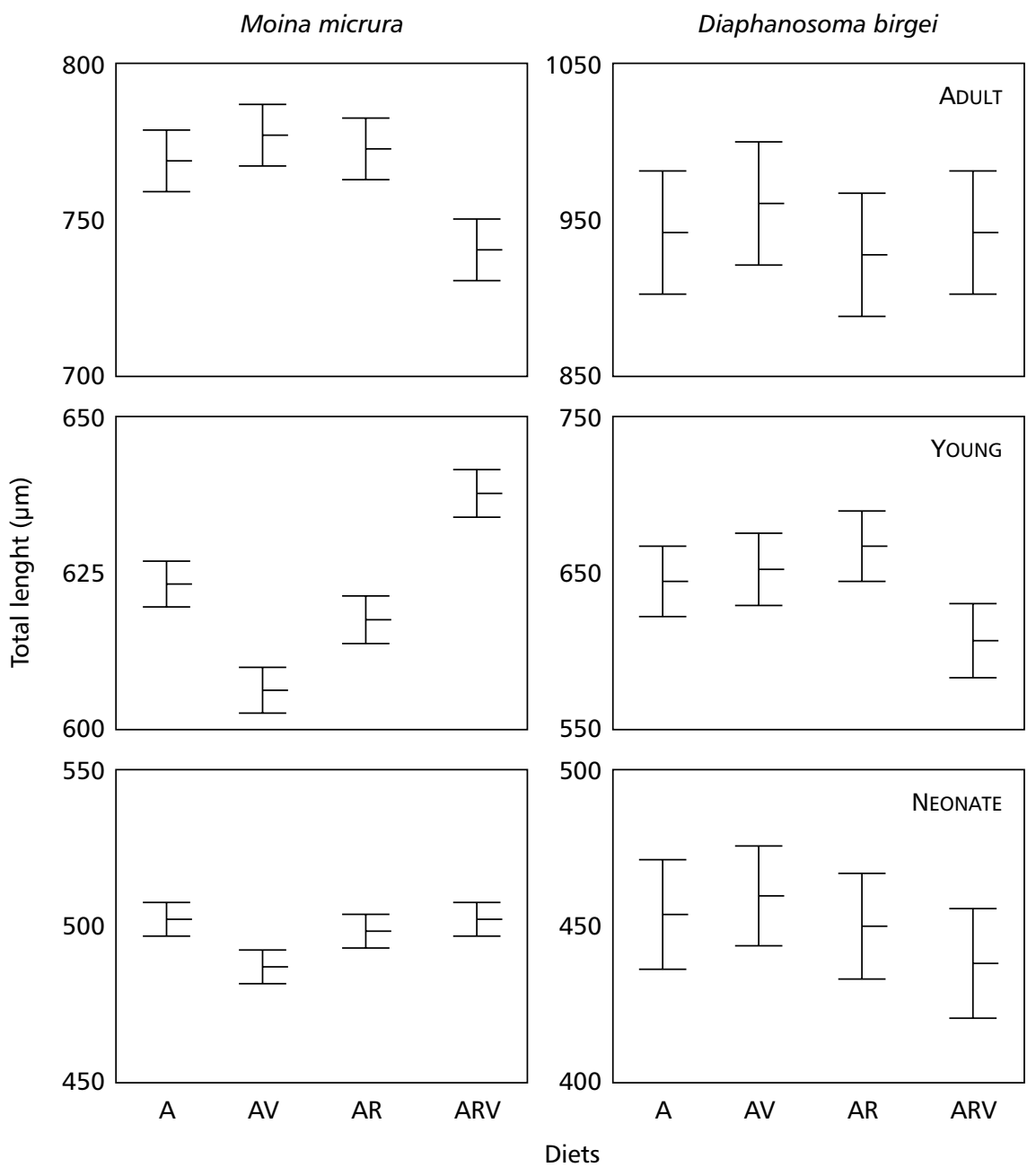

Fig. 1 - Average and standard error of total length $(\mu \mathrm{m})$ for adults, young, and neonates of Moina micrura and Diaphanosoma birgei, treated with algae alone (A), algae + vitamin (AV), algae + ration + vitamin (ARV), and algae + ration (AR).

Generally, AV treatment yielded the best results, and ARV, the worst. This was basycally true for phosphorus, conductivity, and inorganic carbon forms. With respect to nitrogen compounds, treatment A displayed the highest nitrate and nitrite concentrations for M. micrura culture, with averages of 209.4 and $9.9 \mu \mathrm{g} / \mathrm{L}$, respectively.

While the treatments with ration (AR and ARV) displayed the highest ammonia value for the two species, for M. micrura the values were 15.6 and 10.6 $\mu \mathrm{g} / \mathrm{L}$, and for D. birgei, 44.4 and $33.9 \mu \mathrm{g} / \mathrm{L}$, respectively. For ration treatments (AR and ARV), nitrite levels were five times higher than those for A and AV (Table 3).

The alkaline $\mathrm{pH}$ oscillated mildly during the period and conductivity was higher for ARV treatment, probably due to higher nutrient content in this diet, except for nitrite and nitrate in $M$. micrura culture, which was higher in treatment A. Conductivity was higher for treatments containing ration and for $D$. birgei culture as compared to $M$. micrura. Inorganic carbon in the medium was influenced by alkaline $\mathrm{pH}$, with bicarbonate dominating (Table 3). 
TABLE 2

Life history characters of the cladocerans, Moina micrura e Diaphanosoma birgei, treated with algae alone (A), algae + vitamin (AV); algae + ration $(\mathrm{AR})$, and algae + ration + vitamin (ARV).

\begin{tabular}{|c|c|c|c|c|c|c|c|c|}
\hline \multirow{3}{*}{ Characters } & \multicolumn{4}{|c|}{ Moina micrura } & \multicolumn{4}{|c|}{ Diaphanosoma birgei } \\
\hline & \multicolumn{8}{|c|}{ Feeding treatments } \\
\hline & $\mathbf{A}$ & $\mathbf{A V}$ & $\mathbf{A R}$ & ARV & $\mathbf{A}$ & $\mathbf{A V}$ & $\mathbf{A R}$ & ARV \\
\hline Intrinsic rate $(r)$ & 0.50 & 0.69 & 0.43 & 0.43 & 0.37 & 0.57 & 0.42 & 0.44 \\
\hline Mean fecundity (n. neonate/offspring/female) & $5.37 \pm 0.51$ & $8.63 \pm 0.51$ & $5.78 \pm 0.51$ & $7.10 \pm 0.51$ & $7.16 \pm 0.62$ & $8.15 \pm 0.62$ & $6.73 \pm 0.67$ & $8.66 \pm 0.62$ \\
\hline Mean number of offspring/female & $2.30 \pm 0.99$ & $2.83 \pm 0.99$ & $3.97 \pm 0.99$ & $3.05 \pm 0.92$ & $6.17 \pm 2.19$ & $10.08 \pm 2.19$ & $5.46 \pm 1.09$ & $7.65 \pm 2.19$ \\
\hline Mean embryonic duration (hours) & $27.23 \pm 3.75$ & $24.29 \pm 4.02$ & $34.46 \pm 4.02$ & $29.11 \pm 4.02$ & $46.79 \pm 2.14$ & $44.91 \pm 1.88$ & $44.91 \pm 1.87$ & $45.98 \pm 1.87$ \\
\hline Mean postembryonic duration (days) & $1.73 \pm 0.25$ & $1.38 \pm 0.31$ & $1.50 \pm 0.23$ & $2.13 \pm 0.25$ & $2.26 \pm 0.06$ & $2.72 \pm 0.11$ & $2.72 \pm 0.10$ & $2.90 \pm 0.10$ \\
\hline Longevity (days) & 5 & 5 & 6 & 5 & 14 & 16 & 13 & 16 \\
\hline
\end{tabular}


Dissolved oxygen levels were above $67 \%$ saturation, due to constant aeration (Table 3).

In general, chlorophyll $a$ rates for both cultures were high, mainly in treatments ARV for M. micrura and AV, AR, and ARV for D. birgei. For both species, treatment A presented the lowest values with averages of $78.6 \mu \mathrm{g} / \mathrm{L}$ and $89.9 \mu \mathrm{g} / \mathrm{L}$ for $M$. micrura and D. birgei, respectively (Table 3).

\section{DISCUSSION}

In the present work, cladocerans production was 1.3 times higher for the diet containing algae + ration + vitamins compared to the other diets. The addition of vitamins and ration as a support for bacteria production had a positive result on $M$. micrura and D. birgei production.

According to Yu et al. (1994), bacteria are important sources of vitamin $\mathrm{B}_{12}$, thus some zooplanktonic species could grow rapidly when certain bacteria strains are present in the culture. Most vitamins in aqueous media are often found in very low levels (nanograms) and originate from bacterial excretion, phytoplankton, and autholysis of senescent cells. In the laboratory, it is possible to eliminate all unfavorable conditions existing in nature, e.g., predation, illnesses, large temperature variations, and competition for food and space.
Moina micrura
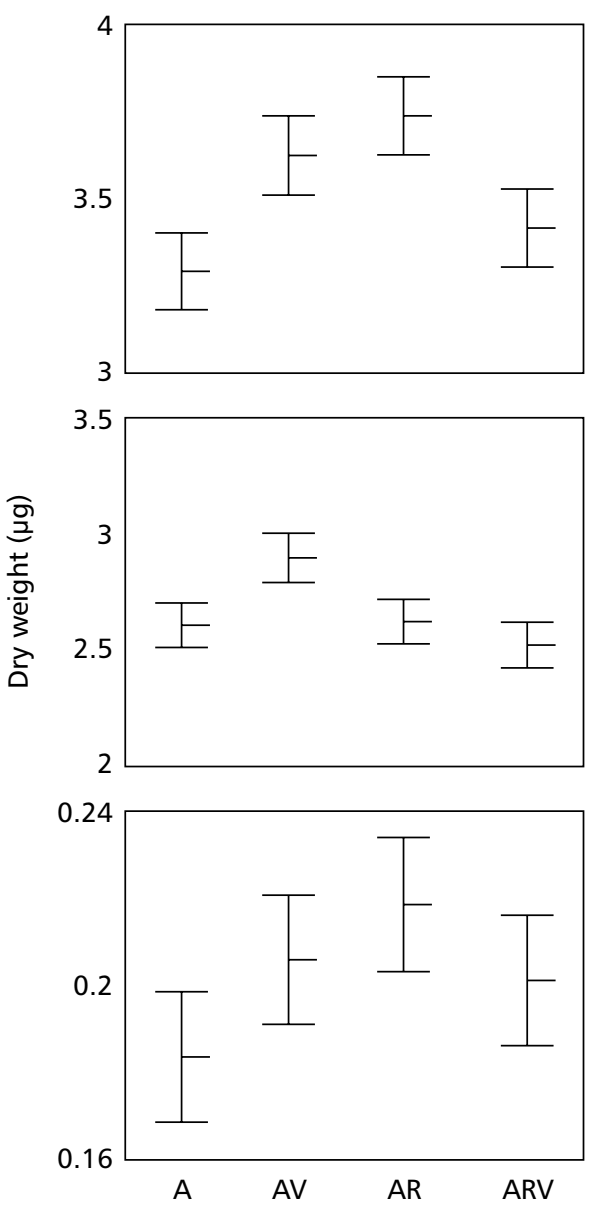

Diaphanosoma birgei
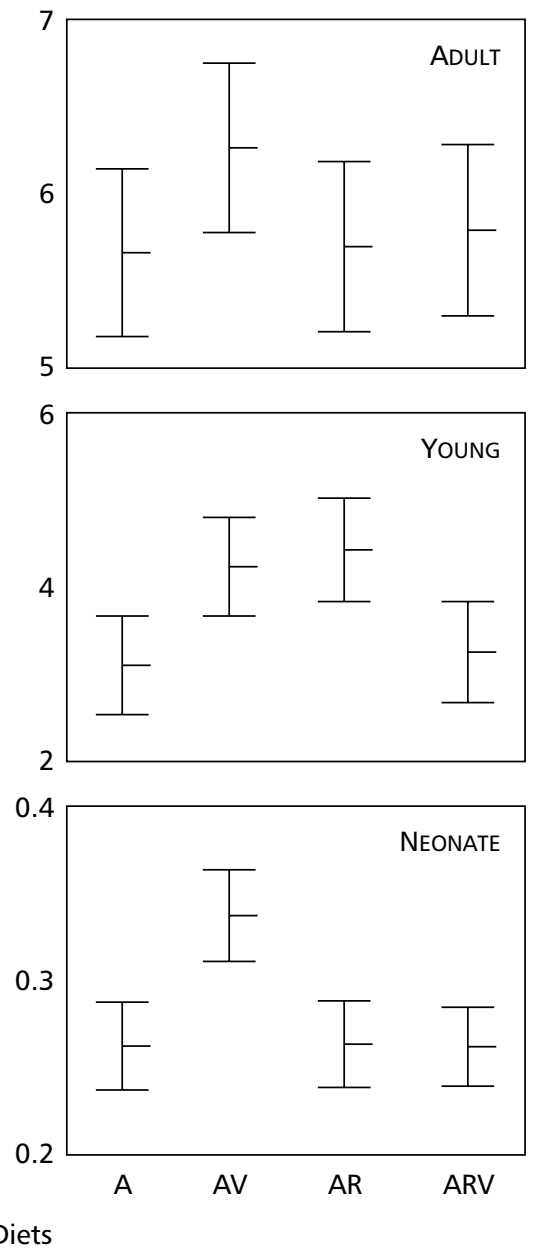

Fig. 2 - Average and standard error of dry weight $(\mu \mathrm{g})$ for adults, young, and neonates of Moina micrura and Diaphanosoma birgei, treated with algae alone (A), algae + vitamin (AV), algae + ration + vitamin (ARV), and algae + ration (AR). 
TABLE 3

Mean variation of limnological variables of the culture water of zooplanctonic species during the experimental period for these feeding treatments: algae alone (A), algae + vitamin (AV), algae + ration + vitamin (ARV), algae + ration $(A R)$, and control $(C)$ (referring to water only, with no treatment).

\begin{tabular}{|c|c|c|c|c|c|c|c|c|c|c|}
\hline \multirow{2}{*}{$\begin{array}{c}\text { Limnological } \\
\text { variables }\end{array}$} & \multirow[t]{2}{*}{$\mathbf{C}$} & \multicolumn{4}{|c|}{ Moina micrura } & \multicolumn{4}{|c|}{ Diaphanosoma birgei } & \multirow{2}{*}{ Units } \\
\hline & & $\mathbf{A}$ & $\mathbf{A V}$ & $\mathbf{A R}$ & AVR & $\mathbf{A}$ & $\mathbf{A V}$ & $\mathbf{A R}$ & AVR & \\
\hline $\mathrm{pH}$ & 7.5 & 7.9 & 7.8 & 7.8 & 7.3 & 7.7 & 7.8 & 7.8 & 7.7 & \\
\hline Conductivity & 25 & 46.0 & 46.0 & 76.1 & 83.3 & 160.0 & 157.0 & 172.0 & 184.0 & $\mu \mathrm{S} / \mathrm{cm}$ \\
\hline Dissolved oxygen & 66.0 & 84.0 & 80.1 & 74.2 & 67.3 & 80.3 & 80.5 & 78.7 & 79.2 & $\%$ SAT \\
\hline Alkalinity & 19.0 & 12.0 & 12.0 & 36.0 & 39.0 & 16.0 & 24.0 & 27.0 & 37.0 & $\mathrm{mg} / \mathrm{L}$ \\
\hline Bicarbonate & 12.2 & 14.6 & 14.6 & 43.7 & 47.5 & 20.2 & 30.0 & 33.7 & 44.6 & $\mathrm{mg} / \mathrm{L}$ \\
\hline Free $\mathrm{CO}_{2}$ & 6.7 & 1.5 & 1.17 & 2.2 & 3.8 & 0.8 & 0.9 & 1.0 & 1.1 & $\mathrm{mg} / \mathrm{L}$ \\
\hline Total $\mathrm{CO}_{2}$ & 18.9 & 16.1 & 15.8 & 46.0 & 51.3 & 22.0 & 31.9 & 35.7 & 46.9 & $\mathrm{mg} / \mathrm{L}$ \\
\hline Ammonia & 0.1 & 4.0 & 6.2 & 15.6 & 10.6 & 15.4 & 16.8 & 44.4 & 33.9 & $\mu \mathrm{g} / \mathrm{L}$ \\
\hline Nitrite & 1.6 & 9.9 & 8.8 & 4.8 & 2.7 & 7.8 & 8.5 & 48.2 & 42.2 & $\mu \mathrm{g} / \mathrm{L}$ \\
\hline Nitrate & 249.1 & 209.4 & 180.6 & 6.6 & 7.0 & 23.1 & 20.8 & 20.2 & 20.1 & $\mu \mathrm{g} / \mathrm{L}$ \\
\hline Total phosphorus & $*$ & 18.0 & 18.8 & 36.6 & 31.0 & 15.1 & 16.2 & 19.0 & 19.5 & $\mathrm{mg} / \mathrm{L}$ \\
\hline Orthophosphate & $*$ & 0.8 & 1.2 & 1.9 & 2.0 & 0.9 & 1.1 & 1.2 & 1.5 & $\mathrm{mg} / \mathrm{L}$ \\
\hline Chlorophyll $a$ & $*$ & 78.6 & 80.8 & 79.2 & 130.8 & 89.8 & 112.3 & 127.3 & 146.2 & $\mu \mathrm{g} / \mathrm{L}$ \\
\hline
\end{tabular}

For cladocerans, $\mathbf{r m}$ varies between 0.2 and 0.6 . In this study, it varied from 0.43 to 0.69 and 0.37 to 0.57 for $M$. micrura and D. birgei, respectively. The highest values were found for $\mathrm{AV}$ treatment and also the highest number of neonates per female for $M$. micrura.

Body size is of fundamental importance in zooplanktonic organism studies because of its relationship with rates of physiological processes such as growth, respiration, feeding, and excretion (Jayatunga, 1986).

M. micrura females were smaller for ARV treatment, probably due to high population density. However, during the juvenile stage, ARV treatment resulted in the largest body size, while the opposite was verified for $D$. birgei at the same developmental stage. Jana \& Pal (1985) observed that $M$. micrura length was strongly affected by population density. Due to space limitations the same effect might have occurred in this study.

Another important factor in population development studies of zooplanktonic organisms is dry weight, which may vary for same-size animals, depending on their nutritional value, lifecycle stage, and reproductive conditions (Rocha \& Matsumura-Tundisi, 1990). In addition, temperature and food concentration influence size, weight, and embryonic and post-embryonic development period of zooplanktonic organisms.

In this study, $D$. birgei embryonic development was not significantly different for any diet. However, M. micrura embryonic development was slower for the algae + ration diet, probably due to its higher ammonia and total phosphorus levels. 

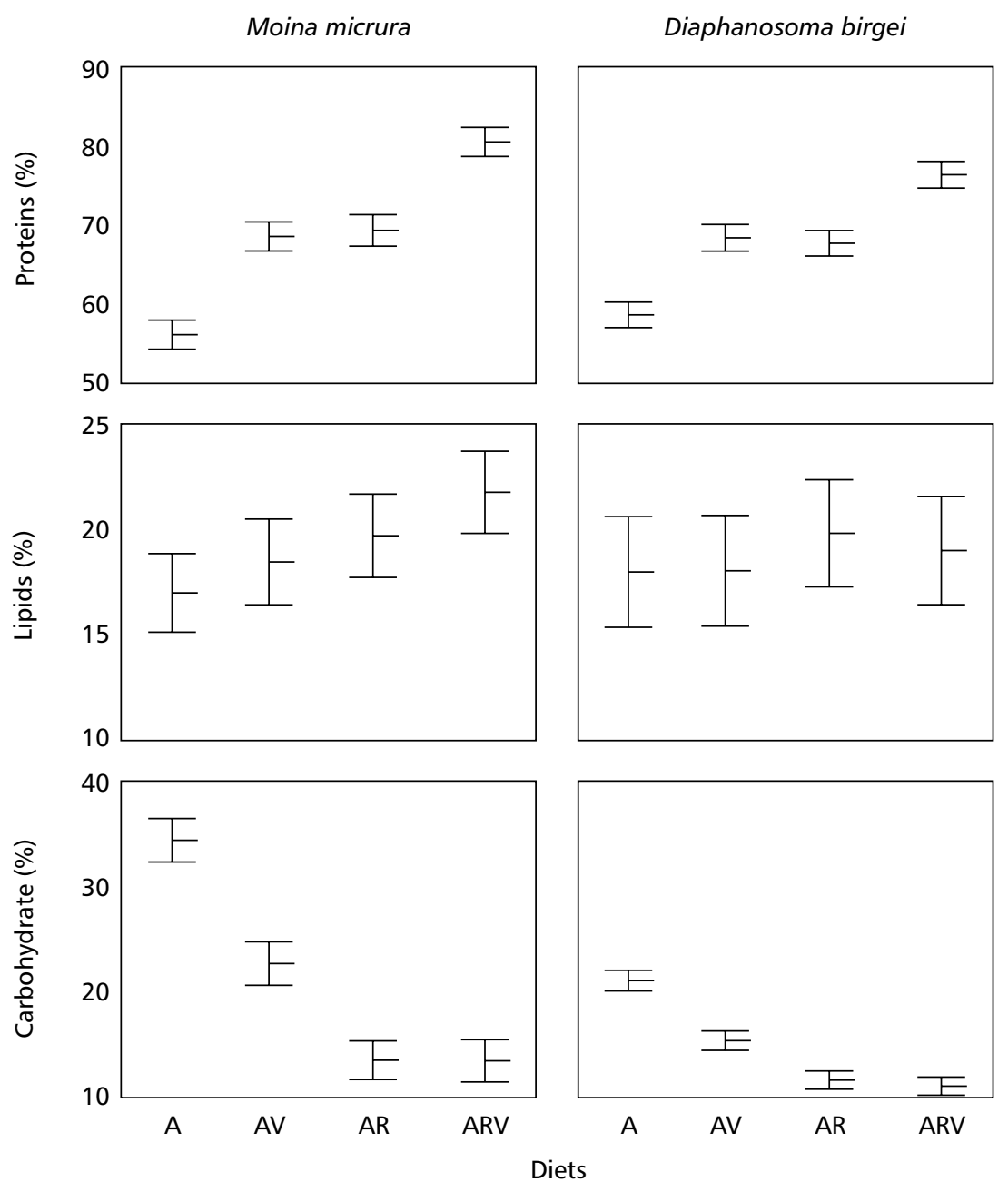

Fig. 3 - Average and standard error of lipid, carbohydrate, and protein percentage (\% dry weight) for Moina micrura and Diaphanosoma birgei, treated with algae alone (A), algae + vitamin (AV), algae + ration + vitamin (ARV), and algae + ration (AR).

Fim (1992), who while studying the biology of M. micrura fed Scenedesmus quadricauda in the laboratory, reported a 21-hour embryonic developmental period. In this work, the fastest development was verified for AV treatment, with a 24.29-hour average, and the slowest for AR treatment, with 34.46 hours for the same species. Embryonic and post-embryonic development of $M$. micrura was faster than that of $D$. birgei for all studied treatments.

Hardy \& Duncan (1994) observed that embryonic and post-embryonic development of Moina reticulata was faster when compared to that of Diaphanosoma sarsi and Daphnia gessneri cultivated in similar conditions. According to these authors, temperature was as important as food quality in determining embryonic and postembryonic development of these three species of tropical cladocerans.

From the results presented, it is evident that food type influenced number of offspring/female. Offspring number for $M$. micrura fed ration treatments, mainly AR, was higher compared to results of $\mathrm{A}$ and $\mathrm{AV}$ without ration. As for $D$. birgei, offspring number was higher for treatments containing vitamins (AV and ARV).

Number of eggs per female is directly affected by the food supply. The studied species 
presented high fecundity, compared to that indicated by values reported by Fim (1992) and Fonseca (1991), due to temperature control and vitamin addition to the treatments.

According to Lynch (1980), larger Daphnidae invest less energy in growth and more in reproduction after they reach maturity. They present higher longevity compared to smaller Daphnidae.

The longevity of $M$. micrura, which was not significantly different $(\mathrm{p}>0.05)$ under any of the treatments, was lower than that of D. Birgei; however, they reached maturity much faster under all treatments. In general, treatments containing vitamins (AV and ARV) presented better results in D. birgei.

It is not yet completely clear which diet is preferable for zooplankton. Food quality is a crucial factor for these organisms, since they store large lipid reserves from the medium depending on their ability to assimilate nutrients from the algae.

According to Kilham et al. (1997), there are intraspecific and interspecific variations in the biochemical composition of live food as well as a large variation in herbivore response to different diets. This complicates the interpretation of feeding studies.

Ration and vitamin additions to the treatments caused higher protein and lipid percentages. However, carbohydrates were higher for the treatment containing algae.

Macedo \& Pinto-Coelho (2000) verified that M. micrura and D. laevis fed Ankistrodemus gracilis presented higher lipid levels compared to those fed Scenedesmus quadricauda.

Water quality also influenced survival and development of these aquatic organisms. In all treatments, limnological parameters were at acceptable levels except for total phosphorus and orthophosphate, probably reflecting excretion and organic matter decomposition accumulation during culture. Moreover, ration addition may have influenced the behavior of these nutrients in the medium.

High percentages of saturated oxygen were associated with constant aeration; ARV treatment displayed the highest concentrations of chlorophyll $a$ due to algal growth caused by nutrients released by the ration via decomposition and presence of vitamins.

Slightly alkaline $\mathrm{pH}$ caused bicarbonate dominance for all treatments and high conductivity in the culture systems was a consequence of nutrient availability due to ration presence, since the highest values found were for AR and ARV.

For the majority of aquatic species, adequate development happens when water $\mathrm{pH}$ is close to neutral.

Moina micrura and Diaphanosoma birgei may be considered promising species for feeding fish larvae and fingerlings in large-scale cultivation. They show high intrinsic rates, short life-span, small size, quick embryonic development, and abundant energy invested in reproduction. In general, diets containing ration and vitamins showed better results in population growth, and protein levels. They can be used as additional components in the diets of planktonic organisms used directly as natural food or indirectly as inoculum in culture ponds to increase system productivity. This diet is economically feasible, considering the low cost of NPK used in the algae culture and the small quantities of vitamin and ration added to improve the growth rates of these zooplanktonic species.

Acknowledgments - We would like to thank CAPES for the grants given and Silvia Regina L. de Laurentiz for helping with laboratory work.

\section{REFERENCES}

BERBEROVIC, R. \& PINTO-COELHO, R. M., 1989, Dry first, measure later: a new procedure to preserve and measure zooplankton for ecophysiological studies. $J$. Plankton Res., 11: 1109-1116.

BOTTRELl, H. H., DUNCAN, A., GLIWICZ, Z. M., GRYGIEREK, E., HERZIG, A., HILLBRICHTILKOWSKA, A., KURASAWA, H., LARSSON, P. \& WEGLENSKA, T., 1976, A review of some problems in zooplankton production studies. Norw. J. Zool., 24: 419456.

DUBOIS, M., GILLES, K. A., HAMILTON, J. K., REBERS, P. A. \& SMITH, F., 1956, Calorimetric method for determination of sugars and related substances. Analyt. Chim., 28: 350-356.

FIM, J. D. I., 1992, Influência da alimentação no ciclo de vida de Moina micrura (Crustacea: Cladocera) em viveiros de peixe. Dissertação de Mestrado, INPA/FVA, Manaus, AM, viii + 148p.

FONSECA, A. L., 1991, A biologia das espécies Daphnia laevis, Ceriodaphnia dúbia silvestrii (Crustacea: Cladocera) e Poecilia reticulata (Pisces, Poecilidae) $e$ o comportamento destes em teste de toxicidade aquática com efluentes industriais. Dissertação de Mestrado, CCBUFSCar, São Carlos, SP, vii + 210p. 
GOLTERMAN, H. L., CLYMO, R. S. \& OHNSTAND, M. A. M., 1978, Methods for physical \& chemical analysis of fresh waters. Blackwell Sci. Publ., London, 213p.

HARDY, E. R. \& DUNCAN, A., 1994, Food concentration and temperature effects on life cycle characteristics of tropical Cladocera (Daphnia gessneri Herbst, Diaphanosoma sarsi Richard, Moina reticulata (Daday)): I. Development time. Acta Amazonica, 24: 119-134.

HARDY, E. R. \& CASTRO, J. G. D., 2000, Qualidade nutricional de três espécies de clorofícias cultivadas em laboratório. Acta Amazonica, 30: 39-47.

JANA, B. B. \& PAL, G. P., 1985, Effects of inoculum density on growth, reproductive potential and population size in Moina micrura (Kurz). Limnologica, 16: 315-324.

JAYATUNGA, Y. N. A., 1986, Influence of food and temperature on the life cycle characteristics of tropical cladocerans species from Kalawewa Reservoir, Sri Lanka. PhD Thesis, Royal Holloway \& Belford New College, University of London, London, 410p.

KILHAM, S. S., KREEGER, D. A., GOULDEN, C. E. \& LYNN, S. G., 1997, Effects of algal food quality on fecundity and population growth rates of Daphnia. Freshwater Biology, 38: 639-647.

KOROLEFF, F., 1976, Determination of nutrients. In: Grassnof, K. (ed.), Methods of sea water analysis. Verlag Cemie, Weinhein., New York.

LOWRY, O. H., ROSEBROUGH, N. J., FARR, A. L. \& RANDALL, R. J., 1951, Protein measurement with the folin phenol reagent. J. Biol. Chem., 193: 265-275.

LYNCH, M., 1980, The evolution of cladoceran life histories. Q. Ver. Biol., 55: 23-42.

MACEDO, C. F. \& PINTO-COELHO, R. M., 2000, Efeito das algas Ankistrodesmus gracilis e Scenedesmus quadricauda no crescimento e no índice lipídico de Daphnia laevis e Moina micrura. Acta Scientiarum, 22: 397-401.
MACKERETH, F. J. H., HERON, J. \& TALLING, J. F., 1978, Water analysis: some revised methods for limnologists. Freshwater Biological Association Scientific Publication n. 36, Titus Wilson \& Sons Ltda, London, 121p.

MEYER, E. \& WALTER, A., 1988, Methods for estimation of protein, lipid, carbohydrate and chitin levels in fresh water invertebrates. Arch. Hydrobiol., 113: 161-177.

PIMENTEL-GOMES, F., 1976, Curso de Estatística Experimental. Livraria Nobel, Piracicaba, 468p.

ROCHA, O. \& MATSUMURA-TUNDISI, T., 1990, Growth rate, longevity and reproductive performance of Daphnia laevis Birge, D. gessneri Herbst and D. ambigua Scourfield in laboratory cultures. Ver. Brasil. Biol., 50: 915-921.

SIPAÚBA-TAVARES, L. H., 1995. Limnologia aplicada à aqüicultura. FUNEP/UNESP, Boletim Técnico n. 1, São Paulo, 72p.

SIPAÚBA-TAVARES, L. H., BACHION, M. A. \& ROCHA, O., 1994, Estudo do crescimento populacional de três espécies zooplanctônicas em laboratório e o uso do plâncton na alimentação de alevinos de Oreochromis niloticus (tilápia) e Astyanax scabripinis paranae (lambari). Rev. Unimar, 16: 189-201.

SIPAÚBA-TAVARES, L. H. \& BRAGA, F. S., 1999, Study on feeding habits of Piaractus mesopotamicus (pacu) larvae in fishpond. Naga. The ICLARM Quarterly, 22: 24-30.

VIJVERBERG, J., 1989, Culture techniques for studies on the growth, development and reproduction of copepods and cladocerans under laboratory and in situ conditions: a review. Freshwat. Biol., 21: 317-373.

WATANABE, T. \& KIRON, V., 1994, Prospects in larval fish dietetics. Aquaculture, 124: 223-251.

YU, J. P., HIRAYAMA, K. \& HINO, A., 1994, The role of bacteria in mass culture of the rotifer Brachionus plicatilis. Bull. Nat. Inst. Aquaculture, 1: 67-70. 